\title{
Analisis Sektor Unggulan dalam Meningkatkan Perekonomian dan Pembangunan Wilayah Provinsi Jambi
}

\author{
${ }^{1}$ Sudirman, M.Alhudori \\ ${ }^{1}$ Fakultas Ekonomi, Universitas Batanghari Jambi
}

\begin{abstract}
Based on pattern classification Typologi Klassen of the growth sectors of the economy in Jambi province makes the agricultural sector and the sector of mining and excavation are on the I quadrant i.e. as a sector that developed and developing fast, water procurement sector, trash, waste treatment and recycling, and education services sectors are at a quadrant II sectors advanced but that is depressed. After dianalis the pattern of growth sectors of the economy, may be known to the classification of economic sectors in the province of Jambi, for a deeper analysis of the sector required base with $L Q$ method to find the base of the sector can be prioritized into the flagship sector. In accordance with the results of the analysis of the economic base by the method of $L Q$ for the level of Jambi province are known to exist in four major sectors constituting the base sector of the economy. The fourth sector is agriculture, a sector of mining and excavation of the procurement sector, garbage, water, sewage treatment and recycling, and educational services. So, from both Typologi and Klassen $L Q$ analysis it can be concluded that the economic sector in Jambi province which should be developed and can be prioritized into a flagship sector is agriculture, a sector of mining and excavation, the sector procurement of waste, water, sewage treatment and recycling, and education services sectors.
\end{abstract}

Keywords: (1) GDP Jambi province; Indonesia'S GDP and (2) the rate of growth of GDP and contribution to Indonesia and Jambi province; (3) Data on the economic potential of Jambi province

\section{PENDAHULUAN}

Pembangunan merupakan tugas bersama yang harus dilaksanakan masyarakat Indonesia dengan tujuan untuk mewujudkan kemakmuran dan kesejahteraan masyarakat Indonesia pada umumnya serta masyarakat daerah pada khususnya. Pembangunan daerah merupakan bagian intregal dari pembangunan nasional yang diarahkan untuk memacu pemerataan pembangunan dan hasilhasilnya dalam rangka meningkatkan kesejahteraan dan peran aktif masyarakat serta meningkatkan pendayagunaan potensi daerah secara optimal (Widiastuti, 2010).

Sudirman dkk (2017:125) Sektor - Sektor Ekonomi Kota Jambi yang memenuhi 4 kriteria. Berdasarkan hasil analisis Tipologi klassen dengan menggunakan variabel PDRB Kota Jambi sebagai daerah analisis dan PDRB provinsi Jambi sebagai daerah acuan menghasilkan 11 sektor ekonomi potensial, 4 sektor ekonomi terbelakang, 1 sektor ekonomi unggulan dan potensial, 1 sektor terbelakang dan berkembang. Sektor Ekonomi Potensial antaranya : Industri pengolahan, Pengadaan listrik dan gas, Pengadaan air, pengelolaan sampah, limbah, kontruksi, transportasi dan pergudangan, penyediaan akomodasi dan makan minum, informasi dan komunikasi, real estate, jasa perusahaan, administrasi pemerintahan, pertahanan dan jaminan social wajib, jasa kesehatan dan kegiatan social. Sector ekonomi terbelakang antara lain: pertanian, kehutanan, 
dan perikanan, sector jasa keuangan dan asuransi, sector jasa pendidikan, jasa lainnya. Sector ekonomi unggulan dan potensial adalah sector perdagangan besar dan eceran;reparasi mobil. Sector ekonomi terbelakang dan berkembang adalah sector pertambangan dan penggalian. Berdasarkan analisis Location Quation sector sector ekonomi yang menjadi basis di Kota Jambi adalah : Industri pengolahan, Pengadaan listrik dan gas, Pengadaan air, pengelolaan sampah, limbah, perdagangan besar dan eceran;reparasi mobil, kontruksi, transportasi dan pergudangan, penyediaan akomodasi dan makan minum, informasi dan komunikasi, jasa perusahaan, administrasi pemerintahan, pertahanan dan jaminan social wajib, jasa kesehatan dan kegiatan social. Non basis pertanian, kehutanan, dan perikanan, pertambangan dan penggalian, jasa keuangan dan asuransi, jasa pendidikan, jasa lainnya. Berdasarkan analisis Incremental Capital Output Ratio (ICOR) sector ekonomi yang memiliki efisiensi ekonomi tinggi adalah pertambangan dan penggalian, industry pengolahan, konstruksi, perdagangan besar dan eceran;reparasi mobil, jasa keuangan dan asuransi, jasa lainnya. Sedangkan efisiensi ekonomi yang rendah adalah sector pertanian, kehutanan dan perikanan.Provinsi Jambi merupakan salah satu provinsi dengan tingkat pendapatan ekonomi yang cukup tinggi. Kondisi ini dapat dilihat dari tingginya laju pertumbuhan ekonomi terhadap Produk Domestik Regional Bruto (PDRB), yang mana PDRB Provinsi Jambi setiap tahunnya terus mengalami peningkatan. Laju pertumbuhan ekonomi pada tahun 2014 mengalami peningkatan dari 7,35 persen. Selanjutnya menurun pada tahun 2015 yaitu sebesar 4,21 persen. Begitu juga pada tahun 2016 menunjukkan kenaikan yang cukup yaitu menjadi pada tahun 2016 sebesar 4,37 persen. terlihat pada tabel berikut :

\section{Tabel 1 Laju Pertumbuhan Ekonomi Sektoral Produk Domestik Regional Bruto di Provinsi Jambi Atas Harga Konstan 2010 Menurut Lapangan} Usaha, Tahun 2014-2016

\begin{tabular}{clccc}
\hline No & Lapangan Usaha & $\mathbf{2 0 1 4}$ & $\mathbf{2 0 1 5}$ & $\mathbf{2 0 1 6}$ \\
\hline 1 & Pertanian & 10,95 & 5,36 & 6,59 \\
2 & Pertambangan \& Penggalian & 4,28 & -0.22 & 0,44 \\
3 & Industri Pengolahan & 4,81 & 2,33 & 0,29 \\
4 & Pengadaan Listrik \& Gas & 9,70 & 4,18 & 6,16 \\
5 & Pengadaan Air, Sampah, Limbah & 4,35 & 4,08 & 5,02 \\
6 & Konstruksi & 8,94 & 2,88 & 3,54 \\
7 & Perdagangan Besar \& Eceran & 8,80 & 11,20 & 6,27 \\
8 & Transportasi \& Pergudangan & 8,18 & 6,59 & 8,29 \\
9 & Penyediaan Akomodasi & 18,73 & 6,49 & 7,65 \\
10 & Informasi dan Komunikasi & 7,01 & 9,83 & 8,51 \\
11 & Jasa Keuangan dan Asuransi & 3,84 & 2,11 & 10,38 \\
12 & Real Estate & 2,20 & 4,19 & 4,31 \\
13 & Jasa Perusahaan & 5,00 & 6,32 & 5,24 \\
14 & Administrasi Pemerintah & 13,38 & 6,79 & 3,01 \\
15 & Jasa Pendidikan & 1,28 & 7,48 & 6,04 \\
16 & Jasa Kesehatan dan Kegiatan Sosial & 15,19 & 10,05 & 6,64 \\
17 & Jasa Lainnya & 5,55 & 8,76 & 6,59 \\
& PDRB & 7,35 & 4,21 & 4,37 \\
\hline
\end{tabular}

Sumber : Badan Pusat Statistik, Provinsi jambi

Berdasarkan tabel 1 kondisi diatas secara sederhana dapat disimpulkan bahwa, laju pertumbuhan PDRB Provinsi Jambi menunjukan bahwa peringkat pertama sumbangan terbesar adalah sektor jasa keuangan dan asuransi yaitu sebesar 10,38 persen pada tahun 2016 serta sektor pertanian yaitu sebesar 6,59 
persen. Karena sektor ini selama kurun waktu 4 tahun telah mampu memberikan kontribusi yang besar terhadap pendapatan daerah Provinsi Jambi. Produk Domestik Regional Buto (PDRB) Provinsi Jambi tahun 2014-2016 atas dasar harga konstan telah berkembang dari Rp 119.991.444,7 juta rupiah pada tahun 2014 kemudian meningkat pada tahun 2015 sebesar Rp.125.036.308 juta rupiah, dan terus mengalami peningkatan menjadi sebesar Rp 130.499.632,1 juta rupiah pada tahun 2016. Perkembangan ini merupakan pertumbuhan perekonomian secara riil dimana faktor inflasi/deflasi sudah dihilangkan. Bagi Provinsi Jambi terdapat tiga sektor yang dapat menyumbankan PDRB dalam jumlah yang besar yaitu sektor pertanian, sektor pertambangan dan penggalian dan sektor industri pengolaha. Dari tiga sektor tersebut kontribusi yang paling banyak yaitu sektor pertanian yaitu Rp.34.932.188,59 juta rupiah pada tahun 2016. Sedangkan untuk sektor pertambangan dan penggalian mengalami peningkatan menjadi Rp. 31.016.887,69 juta rupiah pada tahun 2016 .

Sudirman, susilawati (2017: 9) dari hasil penelitian diketahui constanta sebesar -93.142 ini menyatakan jika IPM (X1) nilainya adalah 0 maka konsumsi makanan rumah tangga di provinsi Jambi sebesar 8,854 persen, dan jika income perkapita (X2) nilainya adalah 0 maka konsumsi makanan rumah tangga di provinsi Jambi sebesar 54,53 persen . Pada koefisien regresi Log X1 (IPM) diperoleh nilai sebesar 39.381 artinya jika IPM mengalami kenaikan $1 \%$, maka jumlah peningkatan konsumsi makanan rumah tangga di Provinsi Jambi akan mengalami peningkatan sebesar $39.381 \%$, sedangka koefisien income perkapita sebesar 3.131 artinya jika icome perkapita naik 1 persen maka konsumsi makanan rumahtangga di provinsi Jambi naik sebesar 3.131 persen dengan asumsi variabel konsumsi nilainya tetap.

Pengaruh IPM terhadap konsumsi makanan di Provinsi Jambi berdasarkan hasil analisis secara parsial dengan menggunakan uji t, diperoleh nilai t hitung sebesar 39.381 dan untuk t tabel pada taraf signifikan sebesar 5\% tt tabel sebesar 1.943 yang menunjukan bahwa $t$ hitung $>\mathrm{t}$ tabel atau $39.381>1.943 \mathrm{ini}$ menunjukan Ha di terima dengan kesimpulan IPM mempunyai pengaruh yang signifikan (positif). Sedangkan t hitung income perkapita sebesar 3.131 lebih besar dari t table 3.131 > 1.943 ini juga menunjukan Ha diterima sehingga icome perkapita mempunyai pengaruh yang signifikan (positif) terhadap konsumsi makan rumah tangga di Provinsi Jambi.

Adapun dalam penelitian ini, berikut rumusan masalah yang akan teliti diantaranya : Bagaimana pola pertumbuhan sektor-sektor ekonomi berdasarkan laju pertumbuhan ekonomi dan kontribusi PDRB sektor perekonomian di Provinsi Jambi, Sektor apa saja yang menjadi unggulan untuk meningkatkan perekonomian wilayah serta bagaimana surplus pendapatan dan dampak pengganda pendapatan dari sektor unggulan di Provinsi Jambi, Sektor apa saja yang memiliki keunggulan kompetitif dan spesialisasi dan bagaimana perubahan struktur perekonomian di Provinsi Jambi serta bagaimana perkembangan pembangunan wilayah dari segi infrastruktur (sarana dan prasarana) yang mendukung perekonomian dan sektor unggulan di Provinsi Jambi

Berdasarkan Latar Belakang dan Rumusan Masalah di atas, maka tujuan yang akan dicapai, diantaranya sebagai berikut : Untuk menganalisis pola pertumbuhan ekonomi berdasarkan laju pertumbuhan ekonomi dan kontribusi PDRB sektor perekonomian di Provinsi Jambi, untuk menganalisis sektor-sektor apa saja yang menjadi unggulan untuk meningkatkan perekonomian wilayah serta untuk menganalisis surplus pendapatan dan pengganda pendapatan sektor 
unggulan di Provinsi Jambi. Untuk mengalisis sektor-sektor apa saja yang memiliki keunggulan kompetitif dan spesialisasi dan untuk menganalisis perubahan struktur perekonomian di Provinsi Jambi serta untuk menganalisis perkembangan pembangunan wilayah dari segi infrastruktur (sarana dan prasarana) yang mendukung perekonomian dan sektor unggulan di Provinsi Jambi.

\section{Landasan Teori \\ Pertumbuhan Ekonomi}

Untuk mengukur seberapa besar kinerja perekonomian suatu wilayah disuatu negara maka dapat dilihat dari kontribusi Produk Domestik Regional Bruto terhadap pembentukan Produk Domestik Bruto (PDB) total nasional. Pertumbuhan ekonomi wilayah adalah pertambahan pendapatan masyarakat yang terjadi di wilayah tersebut yaitu kenaikan seluruh nilai tambah (added value) yang terjadi diwilayah tersebut. Pertumbuhan ekonomi adalah proses kenaikan output perkapita dalam jangka panjang (Tarigan, 2002).

Konsep pertumbuhan tidak berimbang juga mempunyai keterbatasan dalam menggambarkan dan mengatasi permasalahan ekonomi di negara berkembang. Namun para ahli menilai bahwa dalam pembangunan ekonomi di negara berkembang lebih cocok untuk menerapkan konsep pertumbuhan tidak berimbang, sedangkan konsep pertumbuhan berimbang lebih cocok untuk diterapkan di negara-negara maju (Jhingan, 2007:192).

\section{Teori Basis Ekonomi}

Pengertian ekonomi basis di suatu wilayah tidak bersifat statis melainkan dinamis. Artinya pada tahun tertentu mungkin saja sektor tersebut merupakan sektor basis, namun pada tahun berikutnya belum tentu sekor tersebut secara otomatis menjadi sektor basis. Sektor basis bisa mengalami kemajuan ataupun kemunduran. Adapun sebab-sebab kemajuan sektor basis adalah: (1) perkembangan jaringan transportasi dan komunikasi, (2) perkembangan pendapatan dan penerimaan daerah, (3) perkembangan teknologi, dan (4) adanya pengembangan prasarana ekonomi dan sosial. Sedangkan penyebab kemunduran sektor basis adalah: (1) adanya perubahan permintaan di luar daerah, dan (2) kehabisan cadangan sumberdaya.

Analisis basis dan non basis pada umumnya didasarkan atas nilai tambah atau lapangan kerja. Penggabungan lapangan kerja basis dan lapangan kerja non basis merupakan total lapangan kerja yang tersedia untuk wilayah tersebut. Demikian pula penjumlahan pendapatan sektor basis dan pendapatan sektor non basis (Tarigan, 2005).

\section{Pembangunan Ekonomi Daerah}

Pembangunan ekonomi merupakan serangkaian usaha dan kebijakan yang bertujuan untuk meningkatkan taraf hidup masyarakat, memperluas lapangan pekerjaan, memeratakan pembagian pendapatan masyarakat, meningkatkan hubungan ekonomi regional dan mengusahakan pergeseran kegiatan ekonomi dari sektor primer ke sektor sekunder dan sektor tersier. Arah pembangunan ekonomi mengusahakan agar pendapatan masyarakat naik secara mantap dan dengan tingkat pemerataan yang sebaik mungkin. Pembangunan adalah suatu perubahan yang positif, yang meliputi kegiatan-kegiatan yang dilaksanakan beserta hasilhasilnya. Kegiatan-kegiatan ini berlangsung dalam rangka mengelola sumberdaya 
yang dimiliki oleh daerah yang bersangkutan. Hasil-hasil dari pembangunan ini akan tercermin dari pendapatan daerah dan tingkat kesejahteraan penduduknya (Tarigan, 2005).

\section{Produk Domestik Regional Bruto}

Arsyad (2000) menyatakan bahwa pertumbuhan ekonomi daerah diartikan sebagai kenaikan Produk Domestik Regional Bruto (PDRB) tanpa memandang apakah kenaikan itu lebih besar atau lebih kecil dari tingkat pertumbuhan penduduk atau apakah perubahan struktur ekonomi terjadi atau tidak. Hal ini berarti bahwa pertumbuhan ekonomi daerah secara langsung ataupun tidak langsung akan menciptakan lapangan pekerjaan.

\section{Sektor Unggulan}

Darmawansyah (2003) mendefinisikan sektor ekonomi unggulan sebagai sektor yang dapat menunjang dan mempercepat pembangunan dan pertumbuhan perekonomian daerah yang berdasarkan pada kriteria tingkat kemampuan sektor dalam memberi kontribusi terhadap penerimaan PDRB daerah, tingkat kemampuan menyerap tenaga kerja, potensi dalam menghasilkan komoditas eksport dan tingkt keterkaitan yang kuat dengan sektor lainnya.

\section{METODE PENELITIAN}

Metode Analisis Data

Alat analisis yang digunakan dalam studi penelitian ini secara umum terdiri atas tiga metode, yaitu: analisis pola pertumbuhan sektor ekonomi (Klassen Typologi), analisis Location Quotient, analisis Shift Share dan analisis skalogram. Pengolahan data dari ketiga metode/alat analisis yang digunakan dalam penelitian ini diolah dengan menggunakan program Microsoft Excel.

Klasifikasi Klassen Typologi Pendekatan Sektoral:

\begin{tabular}{ccc}
\hline & $\boldsymbol{s i}>\boldsymbol{s}$ & $\boldsymbol{s i}<\boldsymbol{s}$ \\
\hline $\boldsymbol{g} \boldsymbol{i}>\boldsymbol{g}$ & Sektor Maju dan Tumbuh Cepat & Sektor Berkembang Cepat (Potensial) \\
$\boldsymbol{g} \boldsymbol{i}<\boldsymbol{g}$ & Sektor Maju Tapi Tertekan & Sektor Relatif Tertinggal \\
\hline
\end{tabular}

Keterangan:

gi = Laju pertumbuhan PDRB sektoral Provinsi Jambi i

si $=$ Kontribusi PDRB sektoral Provinsi Jambi i

$\mathrm{g}=$ Laju pertumbuhan PDRB sektoral Nasional

$\mathrm{s}=$ Kontribusi PDRB sektoral Nasional

\section{Analisis Location Quotient}

Analisis LQ berguna untuk mengidentifikasi basis ekonomi (sektor basis) suatu wilayah. Dengan analisis ini dapat diketahui seberapa besar tingkat spesialisasi sektor basis atau unggulan (leading sector) di suatu wilayah. Data yang digunakan adalah kesempatan kerja (tenaga kerja) dan PDRB. Dalam penelitian ini data yang digunakan adalah PDRB Analisis LQ mengukur konsentrasi dari suatu kegiatan ekonomi dalam suatu daerah dengan cara membandingkan peranannya dalam perekonomian daerah tersebut dengan peranan kegiatan ekonomi sejenis pada lingkup yang lebih luas (regional atau nasional). Secara matematis rumus LQ sebagai berikut(Emilia, 2006:24):

$$
L Q=\frac{X i j / X j}{Y i / Y}
$$

Keterangan: 
Xij = Nilai Tambah sektor i di Provinsi Jambi

$\mathrm{Xj}=$ Total nilai tambah sektor i di Provinsi Jambi

Yi = Nilai tambah sektor i di Nasional

$\mathrm{Y}=$ Total nilai tambah sektor di Nasional

$\mathrm{Xij} / \mathrm{Xj}=$ Prosentasi employment regional dalam sektor $\mathrm{i}$

$\mathrm{Yi} / \mathrm{Y}=$ Prosentasi empolyment nasional dalam sektor i

\section{Metode Surplus Pendapatan}

Perhitungan surplus bertujuan untuk mengetahui besarnya surplus pendapatan dari penjualan dari aktivitas ekspor dan impor komoditi suatu wilayah disektor perekonomian tertentu. Nilai surplus pendapatan diperoleh dari hasil pengalian indeks surplus pendapatan dengan Produk Domestik Regional Bruto (PDRB) di masing-masing wilayah. Hal ini dapat dirumuskan seperti dibawah ini: $\mathrm{SP}=[\mathrm{Xij} / \mathrm{Xj}-\mathrm{Yi} / \mathrm{Y}] \mathrm{Xij}$

Dimana :

SP $=$ Surplus Pendapatan

$\mathrm{Xij}=$ Pendapatan sektor $\mathrm{i}$ pada tingkat provinsi

$\mathrm{Xj}=$ Total pendapatan semua sektor perekonomian pada tingkat provinsi

$\mathrm{Yi}=$ Pendapatan sektor i pada tingkat Nasional

$\mathrm{Y}=$ Pendapatan total semua sektor perekonomian pada tingkat Nasional.

\section{Pengganda Basis (Multiplier Effect)}

Tarigan (2005), pengganda basis merupakan suatu metode untuk melihat besarnya pengaruh kegiatan ekonomi basis terhadap peningkatan total pendapatan di suatu wilayah. Nilai pengganda basis diperoleh dari pembagian antara jumlah pendapatan total wilayah dengan jumlah pendapatan sektor basis. Maka rumus pengganda basis dapat ditulis secara matematik adalah sebagai berikut:

$\mathrm{K}=\frac{Y}{Y b}$

Dimana:

$\mathrm{K}=$ Koeffisien pengganda basis

$\mathrm{Y}_{\mathrm{b}}=$ Pendapatan sektor basis ekonomi di Provinsi Jambi

$\mathrm{Y}=$ Pendapatan total pendapatan di Provinsi Jambi

Apabila nilai kontribusi (K) sebesar A berarti pada setiap peningkatan nilai kontribusi pendapatan yang dihasilkan pada sektor basis sebesar Rp 1,00 maka terjadi peningkatan terhadap total pendapatan di Provinsi Jambi.

\section{Analisis Shift Share}

Secara matematis, Provincial Share (PS), Proportional Shift (P), danDifferential Shift (D) dapat diformulasikan sebagai berikut :

1. Provincial Share (PS)

2. Proportional Shift $(\mathrm{P})$

$$
P S=Y \text { to i jambi } .\left(\frac{Y \text { t nasional }}{Y \text { to nasional }}-1\right)
$$

3. Differential Shift (D)

$$
P=Y \text { to i jambi. }\left(\frac{Y \text { t i nasional }}{Y \text { to i nasional }}-\frac{Y \text { t nasional }}{Y \text { to nasional }}\right)
$$

Keterangan :

$$
D=Y \text { tO } i \text { jambi }\left(\frac{Y \text { t i jambi }}{Y \text { to } i \text { jambi }}-\frac{Y \text { t i nasional }}{Y \text { to i nasional }}\right)
$$

$\mathrm{Y}=$ nilai tambah bruto

$\mathrm{t} 0=$ tahun awal (2010) 
$\mathrm{t}=$ tahun akhir (2016)

$\mathrm{i}=$ sektor i dalam PDRB

Perubahan (pertumbuhan) nilai tambah bruto sektor tertentu (i) dalam

PDRB Provinsi Jambi merupakan penjumlahan Provincial Share (PS), ProportionalShift (P), dan Differential Shift (D) sebagai berikut:

$$
\Delta \mathrm{Y}=\mathrm{PS}+\mathrm{P}+\mathrm{D}
$$

HASIL PENELITIAN

Identifikasi Pola Pertumbuhan Ekonomi Sektoral Provinsi Jambi dengan

Pendekatan Analisis Tipologi Klassen

Tabel 2 Hasil Perhitungan Laju Pertumbuhan dan Kotribusi PDRB Sektor Ekonomi Provinsi Jambi Tahun 2011-2016

\begin{tabular}{lcccc}
\hline \multicolumn{1}{c}{ Lapangan Usaha } & \multicolumn{2}{c}{ Kontribusi Rata-rata } & \multicolumn{2}{c}{ Laju Pertumbuhan Rata-rata } \\
& Indonesia & Provinsi Jambi & Indonesia & Provinsi jambi \\
\hline Pertanian & 13,33 & 25,81 & 4,00 & 6,75 \\
Pertambangan \& Penggalian & 9,50 & 26,12 & 1,32 & 4,26 \\
Industri Pengolahan & 21,77 & 11,35 & 4,92 & 5,51 \\
Pengadaan Listrik \& Gas & 1,07 & 0,05 & 5,53 & 9,89 \\
Pengadaan Air, Sampah & 0,08 & 0,14 & 4,55 & 3,63 \\
Konstruksi & 9,52 & 6,59 & 6,70 & 9,64 \\
Perdagangan Besar \& Eceran & 13,63 & 8,91 & 5,26 & 8,58 \\
Transportasi \& Pergudangan & 3,76 & 3,07 & 7,36 & 7,53 \\
Penyediaan Akomodasi & 2,97 & 0,98 & 5,88 & 8,88 \\
Informasi dan Komunikasi & 4,29 & 3,31 & 10,23 & 7,76 \\
Jasa Keuangan dan Asuransi & 3,71 & 2,25 & 7,91 & 9,83 \\
Real Estate & 2,96 & 1,51 & 5,84 & 4,57 \\
Jasa Perusahaan & 1,56 & 1,08 & 8,24 & 4,06 \\
Administrasi Pemerintah & 3,58 & 3,44 & 3,55 & 5,97 \\
Jasa Pendidikan & 3,04 & 3,32 & 6,49 & 4,84 \\
Jasa Kesehatan & 1,04 & 1,03 & 7,47 & 8,76 \\
Jasa Lainnya & 1,54 & 1,02 & 7,53 & 5,46 \\
\multicolumn{1}{c}{ JUMLAH } & 100 & 100 & 5,44 & 6,82 \\
\hline
\end{tabular}

Sumber : data diolah, 2017

Tabel 3 Klasifikasi Sektoral Berdasarkan Tipologi Klassen Menggunakan Variabel PDRB

\begin{tabular}{|c|c|c|}
\hline Kriteria & $\bar{g} \mathrm{ij}>\overline{g \mathrm{i}}, \mathrm{N}$ & $\bar{g} \mathrm{ij}<\bar{g} \mathrm{i}, \mathrm{N}$ \\
\hline \multirow{3}{*}{$\bar{S} \mathrm{ij}>\bar{S} \mathrm{i}, \mathrm{N}$} & Sektor yang Maju & Sektor yang Maju tetapi \\
\hline & $\checkmark \quad$ Sektor Pertanian & Tertekan \\
\hline & $\begin{array}{l}\text { Sektor Pertambangan dan } \\
\text { Penggalian }\end{array}$ & $\checkmark \quad$ Sektor Jasa Pendidikan \\
\hline \multirow{15}{*}{$\bar{S} \mathrm{ij}<\bar{S} \mathrm{i}, \mathrm{N}$} & Sektor yang Berkembang & Sektor Tertinggal \\
\hline & $\checkmark \quad$ Sektor Industri Pengolahan & $\checkmark \quad$ Sektor Informasi dan \\
\hline & $\checkmark \quad$ Sektor Pengadaan Listrik dan Gas & Komunikasi \\
\hline & $\checkmark \quad$ Sektor Pengadaan Air, Sampah & $\checkmark \quad$ Sektor Real Estate \\
\hline & $\checkmark \quad$ Sektor Kontruksi & $\checkmark \quad$ Jasa Perusahaan \\
\hline & $\checkmark \quad$ Sektor Perdagangan Besar dan & \\
\hline & Eceran & \\
\hline & $\checkmark \quad$ Sektor Transportasi dan & \\
\hline & Pergudangan & \\
\hline & $\checkmark \quad$ Sektor Penyediaan Akomodasi & \\
\hline & $\checkmark \quad$ Sektor Jasa Keuangan dan Asuransi & \\
\hline & $\checkmark \quad$ Sektor Administrasi Pemerintah & \\
\hline & $\checkmark \quad$ Sektor Jasa Kesehatan dan & \\
\hline & Kegiatan Sosial & \\
\hline & $\checkmark \quad$ Sektor Jasa Lainnya & \\
\hline
\end{tabular}

Sumber : Data diolah 
Analisis Location Quotient (LQ)

Penentuan Sektor Ekonomi Unggulan dengan Pendekatan Analisis Locations Quotient (LQ)

Tabel 4 Nilai LQ Persektor dengan

Menggunakan Variabel PDRB Tahun 2011-2016

\begin{tabular}{lcccccccc}
\hline \multicolumn{1}{c}{ Sektor Lapangan Usaha } & $\mathbf{2 0 1 1}$ & $\mathbf{2 0 1 2}$ & $\mathbf{2 0 1 3}$ & $\mathbf{2 0 1 4}$ & $\mathbf{2 0 1 5}$ & $\mathbf{2 0 1 6}$ & Rata-rata & Ket \\
\hline Pertanian & 1,86 & 1,88 & 1,89 & 1,97 & 2,01 & 2,09 & 1,95 & Basis \\
Pertambangan \& Penggalian & 2,71 & 2,74 & 2,74 & 2,78 & 2,89 & 2,89 & 2,79 & Basis \\
Industri Pengolahan & 0,52 & 0,52 & 0,53 & 0,52 & 0,52 & 0,51 & 0,52 & Non Basis \\
Pengadaan Listrik \& Gas & 0,04 & 0,04 & 0,04 & 0,04 & 0,05 & 0,05 & 0,04 & Non Basis \\
Pengadaan Air, Sampah & 1,86 & 1,79 & 1,74 & 1,69 & 1,66 & 1,69 & 1,74 & Basis \\
Konstruksi & 0,61 & 0,67 & 0,74 & 0,74 & 0,72 & 0,71 & 0,70 & Non Basis \\
Perdagangan Besar \& Eceran & 0,61 & 0,63 & 0,64 & 0,65 & 0,7 & 0,72 & 0,66 & Non Basis \\
Transportasi \& Pergudangan & 0,81 & 0,81 & 0,81 & 0,8 & 0,8 & 0,81 & 0,81 & Non Basis \\
Penyediaan Akomodasi & 0,31 & 0,31 & 0,31 & 0,34 & 0,35 & 0,36 & 0,33 & Non Basis \\
Informasi dan Komunikasi & 0,84 & 0,79 & 0,76 & 0,72 & 0,72 & 0,73 & 0,76 & Non Basis \\
Jasa Keuangan dan Asuransi & 0,63 & 0,62 & 0,63 & 0,61 & 0,58 & 0,59 & 0,61 & Non Basis \\
Real Estate & 0,53 & 0,52 & 0,51 & 0,48 & 0,48 & 0,49 & 0,50 & Non Basis \\
Jasa Perusahaan & 0,76 & 0,73 & 0,68 & 0,64 & 0,63 & 0,62 & 0,68 & Non Basis \\
Administrasi Pemerintah & 0,91 & 0,91 & 0,92 & 1,01 & 1,02 & 1,03 & 0,97 & Non Basis \\
Jasa Pendidikan & 1,15 & 1,12 & 1,08 & 1,01 & 1,02 & 1,05 & 1,07 & Basis \\
Jasa Kesehatan & 0,96 & 0,96 & 0,95 & 0,99 & 1,03 & 1,05 & 0,99 & Non Basis \\
Jasa Lainnya & 0,69 & 0,67 & 0,65 & 0,62 & 0,63 & 0,62 & 0,65 & Non Basis \\
\hline
\end{tabular}

Sumber : Hasil Analisis, 2017

\section{Surplus Pendapatan}

Tabel 5 Nilai Surplus Pendapatan Sektor perekonomian Provinsi Jambi

Tahun 2011-2016 (dalam Rp)

\begin{tabular}{|c|c|c|c|c|c|c|}
\hline Lapangan Usaha & 2011 & 2012 & 2013 & 2014 & 2015 & 2016 \\
\hline Pertanian & 2889,88 & 3121,622 & 3322,218 & 3978,574 & 4314,856 & 4871,196 \\
\hline Pertambangan \& Penggalian & 4803,913 & 4961,151 & 5008,771 & 5112,923 & 4988,084 & 4822,099 \\
\hline Industri Pengolahan & $-1186,86$ & $-1259,92$ & $-1312,02$ & $-1402,58$ & $-1448,01$ & $-1491,69$ \\
\hline Pengadaan Listrik \& Gas & $-0,44074$ & $-0,49631$ & $-0,53987$ & $-0,62034$ & $-0,64498$ & $-0,6858$ \\
\hline Pengadaan Air, Sampah & 0,110201 & 0,098852 & 0,093098 & 0,090613 & 0,092965 & 0,10046 \\
\hline Konstruksi & $-203,893$ & $-206,394$ & $-191,978$ & $-215,565$ & $-240,063$ & $-255,492$ \\
\hline Perdagangan Besar \& Eceran & $-448,568$ & $-467,708$ & $-485,51$ & $-518,209$ & $-470,968$ & $-461,339$ \\
\hline Transportasi \& Pergudangan & $-19,6963$ & $-21,3209$ & $-23,7062$ & $-27,8471$ & $-29,5051$ & $-31,2551$ \\
\hline Penyediaan Akomodasi & $-18,155$ & $-19,6654$ & $-21,3337$ & $-24,3873$ & $-25,4599$ & $-26,9175$ \\
\hline Informasi dan Komunikasi & $-19,7895$ & $-28,6547$ & $-37,6481$ & $-48,7744$ & $-54,9298$ & $-61,34$ \\
\hline Jasa Keuangan dan Asuransi & $-28,2783$ & $-32,4106$ & $-36,3721$ & $-39,5985$ & $-45,4605$ & $-50,5977$ \\
\hline Real Estate & $-20,8611$ & $-22,9832$ & $-25,0492$ & $-26,8579$ & $-27,5925$ & $-28,4185$ \\
\hline Jasa Perusahaan & $-3,94695$ & $-4,6762$ & $-5,7459$ & $-7,1804$ & $-7,92147$ & $-8,72801$ \\
\hline Administrasi Pemerintah & $-11,9206$ & $-10,9343$ & $-10,2667$ & $-0,35194$ & 3,755413 & 4,518614 \\
\hline Jasa Pendidikan & 14,24121 & 12,28279 & 9,271096 & 1,823109 & 3,036959 & 6,960055 \\
\hline Jasa Kesehatan & $-0,33414$ & $-0,39419$ & $-0,56595$ & $-0,09828$ & 0,4515 & 0,854791 \\
\hline Jasa Lainnya & $-4,6826$ & $-5,17622$ & $-5,77118$ & $-6,93491$ & $-7,61259$ & $-8,39989$ \\
\hline TOTAL & 5740,721 & 6014,423 & 6183,845 & 6774,407 & 6952,111 & 7280,866 \\
\hline
\end{tabular}

Sumber : Hasil Analisis, 2017 
Efek Pengganda Pendapatan (Multiplier Effect)

Tabel 6 Nilai Pengganda Pendapatan (Multiplier Effect) Provinsi Jambi

Tahun 2011-2016

\begin{tabular}{crrr}
\hline \multirow{2}{*}{ Tahun } & \multicolumn{3}{c}{ BASE MULTIPLIER } \\
& \multicolumn{1}{c}{ Yotal } & Y Basis & K (Multiplier) \\
\hline 2011 & $97.740,00$ & $95.795,28$ & 1,02 \\
2012 & $104.615,10$ & $102.356,56$ & 1,02 \\
2013 & $111.766,00$ & $108.981,81$ & 1,03 \\
2014 & 119.991 .70 & $117.000,65$ & 1,03 \\
2015 & $125.036,00$ & $121.107,34$ & 1,03 \\
2016 & $130.499,10$ & $125.839,05$ & 1,04 \\
\hline
\end{tabular}

Sumber : Hasil diolah

Tabel 7 Nilai Pengganda Basis Masing-masing Sektor Basis di Provinsi Jambi Tahun 2011-2016

\begin{tabular}{|c|c|c|c|c|}
\hline \multirow[b]{2}{*}{ Tahun } & \multicolumn{4}{|c|}{ BASE MULTIPLIER PER SEKTOR BASIS } \\
\hline & Pertanian & $\begin{array}{l}\text { Pertambangan dan } \\
\text { Penggalian }\end{array}$ & $\begin{array}{c}\text { Pengadaan Air,Sampah,Limbah } \\
\text { dan Daur Ulang }\end{array}$ & $\begin{array}{c}\text { Jasa } \\
\text { Pendidikan }\end{array}$ \\
\hline 2011 & 1,86 & 2,71 & 1,86 & 1,15 \\
\hline 2012 & 1,88 & 2,74 & 1,79 & 1,12 \\
\hline 2013 & 1,89 & 2,74 & 1,74 & 1,08 \\
\hline 2014 & 1,97 & 2,78 & 1,69 & 1,02 \\
\hline 2015 & 2,01 & 2,89 & 1,66 & 1,02 \\
\hline 2016 & 2,09 & 2,89 & 1,69 & 1,05 \\
\hline
\end{tabular}

Sumber : Hasil diolah

Analisis Shift-Share

Hasil Analisis Shift-Share tentang keunggulan kompetitif dan spesialisasi sektor ekonomi di Provinsi jambi

Tabel 8 Hasil Analisis Shift-Share tentang Keunggulan Kompetitif dan Spesialisasi Menurut Sektor di Provinsi Jambi

\begin{tabular}{clrr}
\hline No. & Lapangan Usaha & K-K & \multicolumn{1}{c}{ S-S } \\
\hline 1 & Pertanian & 2,753 & 13502 \\
2 & Pertambangan \& Penggalian & 2,943 & 18683 \\
3 & Industri Pengolahan & 0,595 & -11082 \\
4 & Pengadaan Listrik \& Gas & 4,360 & -1111 \\
5 & Pengadaan Air, Sampah & $-0,922$ & 69,32 \\
6 & Konstruksi & 2,931 & -3093 \\
7 & Perdagangan Besar \& Eceran & 3,323 & -5132 \\
8 & Transportasi \& Pergudangan & 0,165 & $-719,5$ \\
9 & Penyediaan Akomodasi & 2,994 & -2156 \\
10 & Informasi dan Komunikasi & $-2,472$ & $-992,4$ \\
11 & Jasa Keuangan dan Asuransi & 1,917 & -1493 \\
12 & Real Estate & $-1,273$ & -1551 \\
13 & Jasa Perusahaan & $-4,182$ & $-495,9$ \\
14 & Administrasi Pemerintah & 2,419 & $-155,7$ \\
15 & Jasa Pendidikan & $-1,653$ & 314,48 \\
16 & Jasa Kesehatan & 1,291 & $-5,213$ \\
17 & Jasa Lainnya & $-2,068$ & $-554,3$ \\
\hline
\end{tabular}

Sumber : Hasil Analisis, 2017

Keterangan :

$\mathrm{K}-\mathrm{K}$ : Keunggulan Kompetitif

$\mathrm{S}-\mathrm{S} \quad$ : Keunggulan Spesialisasi 
Identifkasi Perubahan Struktur Perekonomian Sektor Ekonomi di Provinsi Jambi

Tabel 9 Analisis Shift-Share Provinsi Jambi Terhadap Indonesia Menurut Lapangan Usaha 2011-2016 (Juta Rupiah)

\begin{tabular}{lrrrrr}
\hline \multicolumn{1}{c}{ Lapangan Usaha } & $\begin{array}{r}\text { Pertumbuhan } \\
(\mathbf{G})\end{array}$ & Total Shift & $\begin{array}{c}\text { National } \\
\text { Shift }\end{array}$ & $\begin{array}{c}\text { Proporsiona } \\
\text { l Shift }\end{array}$ & $\begin{array}{c}\text { Differential } \\
\text { Shift }\end{array}$ \\
\hline Pertanian & $10.187,22$ & $-17.773,83$ & $7.175,87$ & $-1802,41$ & $4.814,76$ \\
Pertambangan dan Penggalian & $3.751,10$ & $-4.850,77$ & $7.907,02$ & $-6941,23$ & $2.785,31$ \\
Industri Pengolahan & $3.050,75$ & $-6.690,06$ & $3.252,97$ & $-391,18$ & 188,97 \\
Pengadaan Listrik \& Gas & 24,28 & $-455,13$ & 12,69 & 0,62 & 10,97 \\
Pengadaan Air, Sampah & 26,21 & $-70,19$ & 44,28 & $-6,65$ & $-11,42$ \\
Konstruksi & $3.537,42$ & $-6.775,01$ & $1.629,71$ & 357,27 & $1.549,44$ \\
Perdagangan Besar \& Eceran & $4.261,22$ & $-7.265,51$ & $2.412,16$ & $-425,27$ & $2.274,33$ \\
Transportasi \& Pergudangan & $1.335,55$ & $-3.087,12$ & 841,25 & 359,27 & 134,03 \\
Penyediaan Akomodasi & 504,40 & $-952,67$ & 261,30 & 25,731 & 218,37 \\
Informasi dan Komunikasi & $1.452,08$ & $-4.362,88$ & 918,53 & 1076,99 & $-543,44$ \\
Jasa Keuangan dan Asuransi & 948,89 & $-2.424,12$ & 626,23 & 399,33 & $-76,67$ \\
Real Estate & 353,14 & $-927,08$ & 443,63 & 22,46 & $-111,95$ \\
Jasa Perusahaan & 274,42 & $-924,75$ & 319,41 & 200,39 & $-244,39$ \\
Administrasi Pemerintah & $1.195,42$ & $-1.914,45$ & 974,21 & $-443,98$ & 666,19 \\
Jasa Pendidikan & 971,83 & $-2.539,74$ & 958,47 & 253,46 & $-239,1$ \\
Jasa Kesehatan & 552,81 & $-1.163,04$ & 272,25 & 112,44 & 167,12 \\
Jasa Lainnya & 330,52 & $-906,63$ & 294,85 & 140,44 & $-104,78$ \\
$\quad$ JUMLAH & $\mathbf{3 2 . 7 5 8 , 2 6}$ & $\mathbf{- 6 2 . 6 7 6 , 9 8}$ & $\mathbf{2 8 . 3 4 4 , 8 3}$ & $\mathbf{- 7 0 6 2 , 3}$ & $\mathbf{1 1 . 4 7 7 , 7 4}$ \\
\hline
\end{tabular}

Sumber : Hasil Analisis, 2017

Tabel 10 Nilai Perhitungan National Share (Ns) Provinsi Jambi dengan Menggunakan Variabel PDRB Tahun 2011-2016 (Juta Rupiah)

\begin{tabular}{|c|c|c|c|c|c|}
\hline No & Lapangan Usaha & $\begin{array}{c}\text { Y r,i, t-n } \\
\text { (a) }\end{array}$ & $\begin{array}{c}\text { Y N,t / Y N, } \\
\text { t-n } \\
\text { (b) }\end{array}$ & $\begin{array}{c}\text { (c) } \\
\text { (a) } \mathbf{x}(\mathbf{b})\end{array}$ & $\begin{array}{c}\text { National Share } \\
\text { (c) }- \text { (a) }\end{array}$ \\
\hline 1 & Pertanian & $24.744 .879,37$ & 1,29 & 31920,24 & $7.175,87$ \\
\hline 2 & Pertambangan dan Penggalian & $27.265 .306,59$ & 1,29 & 35172,61 & $7.907,02$ \\
\hline$\overline{3}$ & Industri Pengolahan & $11.217 .086,13$ & 1,29 & 14470,1 & $3.252,97$ \\
\hline 4 & Pengadaan Listrik \& Gas & $43.503,75$ & 1,29 & 56,4375 & 12,69 \\
\hline 5 & Pengadaan Air, Sampah & $152.528,69$ & 1,29 & 196,9701 & 44,28 \\
\hline 6 & Konstruksi & $5.619 .306,69$ & 1,29 & 7249,4 & $1.629,71$ \\
\hline 7 & Perdagangan Besar \& Eceran & $8.317 .948,80$ & 1,29 & 10729,96 & $2.412,16$ \\
\hline 8 & Transportasi \& Pergudangan & $2.900 .035,86$ & 1,29 & 3742,109 & 841,25 \\
\hline 9 & Penyediaan Akomodasi & $901.249,03$ & 1,29 & 1162,329 & 261,30 \\
\hline 10 & Informasi dan Komunikasi & $3.167 .300,33$ & 1,29 & 4085,856 & 918,53 \\
\hline 11 & Jasa Keuangan dan Asuransi & $2.159 .686,41$ & 1,29 & 2785,639 & 626,23 \\
\hline 12 & Real Estate & $1.529 .293,75$ & 1,29 & 1973,378 & 443,63 \\
\hline 13 & Jasa Perusahaan & $1.101 .916,43$ & 1,29 & 1420,845 & 319,41 \\
\hline 14 & Administrasi Pemerintah & $3.359 .842,33$ & 1,29 & 4333,536 & 974,21 \\
\hline 15 & Jasa Pendidikan & $3.305 .875,07$ & 1,29 & 4263,54 & 958,47 \\
\hline 16 & Jasa Kesehatan & $938.222,8$ & 1,29 & 1211,052 & 272,25 \\
\hline \multirow[t]{2}{*}{17} & Jasa Lainnya & $1.016 .891,73$ & 1,29 & 1311,582 & 294,85 \\
\hline & JUMLAH & $97.740 .874,00$ & 21,93 & 126085,6 & $28.344,83$ \\
\hline
\end{tabular}

Sumber : Hasil Analisis, 2017 
Tabel 11 Nilai Perhitungan Proportional Share (Ps) Provinsi Jambi dengan Menggunakan Variabel PDRB Tahun 2011-2016 (Juta Rupiah)

\begin{tabular}{|c|c|c|c|c|c|c|}
\hline No & Lapangan Usaha & $\begin{array}{c}\text { Y r,i, t-n } \\
\text { (a) }\end{array}$ & $\begin{array}{l}\text { Y N.i.t+m } \\
\text { / Y N.i.t } \\
\text { (b) }\end{array}$ & $\begin{array}{c}\text { Y N.t+m } \\
/ \text { Y N.t } \\
\text { (c) }\end{array}$ & $\begin{array}{c}\text { (d) } \\
\text { (b) }- \text { (c) }\end{array}$ & $\begin{array}{l}\text { Proportional } \\
\text { Share } \\
\text { (a) } \mathrm{x}(\mathrm{d})\end{array}$ \\
\hline 1 & Pertanian & $24.744 .879,37$ & 1,22 & 1,29 & $-0,07$ & $-1802,41$ \\
\hline & Pertambangan dan & & & & & \\
\hline 2 & Penggalian & $27.265 .306,59$ & 1,03 & 1,29 & $-0,25$ & $-6941,23$ \\
\hline 3 & Industri Pengolahan & $11.217 .086,13$ & 1,25 & 1,29 & $-0,03$ & $-391,18$ \\
\hline 4 & Pengadaan Listrik \& Gas & $43.503,75$ & 1,30 & 1,29 & 0,01 & 0,62 \\
\hline 5 & Pengadaan Air, Sampah & $152.528,69$ & 1,25 & 1,29 & $-0,04$ & $-6,65$ \\
\hline 6 & Konstruksi & $5.619 .306,69$ & 1,35 & 1,29 & 0,06 & 357,27 \\
\hline 7 & Perdagangan Besar \& & & & & & \\
\hline & Eceran & $8.317 .948,80$ & 1,24 & 1,29 & $-0,05$ & $-425,27$ \\
\hline 8 & Transportasi \& Pergudangan & $2.900 .035,86$ & 1,41 & 1,29 & 0,12 & 359,27 \\
\hline 9 & Penyediaan Akomodasi & $901.249,03$ & 1,32 & 1,29 & 0,03 & 25,731 \\
\hline 10 & Informasi dan Komunikasi & $3.167 .300,33$ & 1,63 & 1,29 & 0,34 & 1076,99 \\
\hline 11 & Jasa Keuangan dan Asuransi & $2.159 .686,41$ & 1,47 & 1,29 & 0,18 & 399,33 \\
\hline 12 & Real Estate & $1.529 .293,75$ & 1,30 & 1,29 & 0,01 & 22,46 \\
\hline 13 & Jasa Perusahaan & $1.101 .916,43$ & 1,47 & 1,29 & 0,18 & 200,39 \\
\hline 14 & Administrasi Pemerintah & $3.359 .842,33$ & 1,16 & 1,29 & $-0,13$ & $-443,98$ \\
\hline 15 & Jasa Pendidikan & $3.305 .875,07$ & 1,37 & 1,29 & 0,08 & 253,46 \\
\hline 16 & Jasa Kesehatan & $938.222,8$ & 1,41 & 1,29 & 0,12 & 112,44 \\
\hline 17 & Jasa Lainnya & $1.016 .891,73$ & 1,43 & 1,29 & 0,14 & 140,44 \\
\hline & JUMLAH & $97.740 .874,00$ & 22,67 & 21,93 & 0,69 & $-7062,3$ \\
\hline
\end{tabular}

Sumber : Hasil Analisis, 2017

Tabel 12 Nilai Perhitungan Differential Share (Ds) Provinsi Jambi dengan Menggunakan Variabel PDRB Tahun 2011-2016 (Juta Rupiah)

\begin{tabular}{|c|c|c|c|c|c|c|}
\hline No & Lapangan Usaha & $\begin{array}{c}\text { Y r,i, t } \\
\text { (a) }\end{array}$ & $\begin{array}{c}\text { Y N.i.t+m / } \\
\text { Y N.i.t } \\
\text { (b) }\end{array}$ & $\begin{array}{c}\text { Y r.i.t-n } \\
\text { (c) }\end{array}$ & $\begin{array}{c}\text { (d) } \\
\text { (b) } \mathbf{x}(\mathbf{c})\end{array}$ & $\begin{array}{c}\text { Differential } \\
\text { Share } \\
(\mathbf{a})-(\mathbf{d})\end{array}$ \\
\hline $\mathbf{1}$ & Pertanian & $34.932 .188,59$ & 1,22 & $24.744 .879,37$ & 30117,83 & $4.814,76$ \\
\hline 2 & Pertambangan dan Penggalian & $31.016 .887,69$ & 1,03 & $27.265 .306,59$ & 28231,38 & $2.785,31$ \\
\hline 3 & Industri Pengolahan & $14.267 .736,88$ & 1,25 & $11.217 .086,13$ & 14078,91 & 188,97 \\
\hline 4 & Pengadaan Listrik \& Gas & $68.265,03$ & 1,30 & $43.503,75$ & 57,06236 & 10,97 \\
\hline 5 & Pengadaan Air, Sampah & $178.688,90$ & 1,25 & $152.528,69$ & 190,3197 & $-11,42$ \\
\hline 6 & Konstruksi & $9.156 .964,11$ & 1,35 & $5.619 .306,69$ & 7606,669 & $1.549,44$ \\
\hline 7 & Perdagangan Besar \& Eceran & $12.579 .058,02$ & 1,24 & $8.317 .948,80$ & 10304,69 & $2.274,33$ \\
\hline 8 & Transportasi \& Pergudangan & $4.235 .228,41$ & 1,41 & $2.900 .035,86$ & 4101,379 & 134,03 \\
\hline 9 & Penyediaan Akomodasi & $1.406 .109,43$ & 1,32 & $901.249,03$ & 1188,06 & 218,37 \\
\hline 10 & Informasi dan Komunikasi & 4.619.679,41 & 1,63 & $3.167 .300,33$ & 5162,846 & $-543,44$ \\
\hline 11 & Jasa Keuangan dan Asuransi & $3.108 .019,30$ & 1,47 & $2.159 .686,41$ & 3184,972 & $-76,67$ \\
\hline 12 & Real Estate & $1.883 .127,89$ & 1,30 & $1.529 .293,75$ & 1995,835 & $-111,95$ \\
\hline 13 & Jasa Perusahaan & $1.376 .795,85$ & 1,47 & $1.101 .916,43$ & 1621,238 & $-244,39$ \\
\hline 14 & Administrasi Pemerintah & $4.555 .652,75$ & 1,16 & $3.359 .842,33$ & 3889,557 & 666,19 \\
\hline 15 & Jasa Pendidikan & $4.277 .114,90$ & 1,37 & $3.305 .875,07$ & 4516,998 & $-239,1$ \\
\hline 16 & Jasa Kesehatan & $1.490 .993,61$ & 1,41 & $938.222,8$ & 1323,494 & 167,12 \\
\hline \multirow[t]{2}{*}{17} & Jasa Lainnya & $1.347 .121,25$ & 1,43 & $1.016 .891,73$ & 1452,027 & $-104,78$ \\
\hline & JUMLAH & $130.499 .632,10$ & 22,67 & $97.740 .874,00$ & $119.023,3$ & $11.477,74$ \\
\hline
\end{tabular}




\section{Tabel 13 Klasifikasi Sektoral Berdasarkan Nilai Proportional Share (PS) dan} Differential Share (DS) dengan Menggunakan Variabel PDRB Tahun 2011-2016 Provinsi Jambi

\begin{tabular}{|c|c|c|}
\hline Kriteria & DS > 0 & DS $<0$ \\
\hline \multirow[t]{11}{*}{$\mathbf{P S}>\mathbf{0}$} & Unggulan/Prima & Potensial \\
\hline & $\checkmark \quad$ Sektor Pengadaan Listrik dan & $\checkmark \quad$ Sektor Pengadaan Sampah, \\
\hline & Gas & Air, Pengolahan Limbah dan \\
\hline & $\checkmark \quad$ Sektor Kontruksi & Daur Ulang \\
\hline & $\checkmark \quad$ Sektor Transportasi dan & $\checkmark \quad$ Sektor Informasi dan \\
\hline & Pergudangan & Komunikasi \\
\hline & $\checkmark \quad$ Sektor Penyediaan & $\checkmark \quad$ Sektor Jasa Keuangan \\
\hline & Akomodasi & $\checkmark \quad$ Sektor Real Estate \\
\hline & $\checkmark$ Sektor Jasa Kesehatan dan & $\checkmark \quad$ Sektor Jasa Perusahaan \\
\hline & Jaminan Sosial & $\checkmark \quad$ Sektor Jasa Pendidikan \\
\hline & & $\checkmark \quad$ Sektor Jasa Lainnya \\
\hline \multirow[t]{7}{*}{$\mathbf{P S}<0$} & Berkembang & Tertinggal \\
\hline & $\checkmark \quad$ Sektor Pertanian & $\checkmark \quad$ Sektor Administrasi \\
\hline & $\checkmark \quad$ Sektor Industri Pengolahan & pemerintah \\
\hline & $\checkmark \quad$ Sektor Pertambangan dan & \\
\hline & Penggalian & \\
\hline & $\checkmark \quad$ Sektor Perdagangan Besar dan & \\
\hline & Eceran & \\
\hline
\end{tabular}

Sumber : Hasil Analisis, 2017

\section{SIMPULAN}

Hasil dari analisis Klassen Typologi dengan pendekatan sektoral, menunjukkan bahwa sektor pertanian, dan sektor pertambangan dan penggalian menduduki kuadran I yaitu sektor maju dan tumbuh cepat. Disusul oleh sektor pengadaan air, sampah, pengolahan limbah dan daur ulang, dan sektor jasa pendidikan pada kuadran II yaitu sektor maju tetapi tertekan. Selain dari dua sektor ini, sektor ekonomi di Provinsi Jambi masih banyak berada pada kuadran III yaitu sektor yang sedang berkembang. Dan tiga sektor ekonomi lainnya yaitu sektor informasi dan komunikasi, sektor real estate dan sektor jasa perusahaan berada pada kuadran IV yaitu sektor yang relatif tertinggal. Hasil perhitungan nilai LQ diseluruh sektor perekonomian berdasarkan indikator pendapatan daerah yaitu PDRB atas dasar harga konstan 2010 terdapat empat sektor yang menjadi basis perekonomian Provinsi Jambi yang dapat diprioritaskan menjadi sektor unggulan pada tahun 2011-2016 yaitu sektor pertanian, sektor pertambangan dan penggalian, sektor pengadaan air, sampah, pengolahan limbah dan daur ulang, dan sektor jasa pendidikan. Hal ini menunjukkan bahwa sektor-sektor tersebut memiliki kontribusi yang besar dalam perekonomian dan pembangunan wilayah di Provinsi Jambi. Keempat sektor tersebut memiliki nilai surplus pendapatan dan pengganda pendapatan yang positif dan cenderung meningkat. Hasil analisis Shift-Share di Provinsi Jambi menunjukkan hasil bahwa terdapat beberapa sektor yang memiliki keunggulan/daya saing kompetitif maupun spesialisasi. Sektor tersebut antara lain: sektor pertanian, dan sektor pertambangan dan penggalian. Adapun proporsi tiap komponen dalam analisis shift-share Provinsi Jambi, sektor yang memiliki nilai differential shift dan proportional shift yang positif ada empat sektor, antara lain : pengadaan listrik dan gas, sektor kontruksi, sektor transportasi dan pergudangan, sektor penyediaan akomodasi, dan sektor jasa kesehatan. Artinya, sektor ini memiliki keunggulan secara lokasi di bandingkan dengan provinsi lain dan merupakan sektor yang berkembang relatif pesat di Indonesia. Hasil analisis skalogram Kota Jambi memegang peringkat pertama dalam 
ketersediaan fasilitas pembangunan. Peringkat terendah dipegang oleh Kabupaten Sungai Penuh. Jika dilihat dari hasil metode skalogram Kota Jambi berada pada peringkat ketiga, dan Kabupaten Sungai Penuh tetap peringkat terakhir. Perusahaan yang mendukung peranan sektor unggulan tersebar di beberapa kabupaten/kota yang memiliki potensi sumberdaya alam dan lokasi perkebunan yang luas.

\section{DAFTAR PUSTAKA}

Arsyad, L. 2000. Pengantar Perencanaan dan Pebangunan Ekonomi Daerah. UGM, Yogyakarta.

Anwar, A. 2005. Ketimpangan Pembangunan Wilayah dan Perdesaan. P4Wpress. Bogor.

Agus, T. 2009. Analisis Potensi Unggulan Kabupaten Yapen dalam Menompang Pembangunan Provinsi Papua Tahun 2004-2008. Jurnal, Papua.

Anthy, S. 2007. Studi Penentuan Komoditas Unggulan Subsektor Perkebunan Dalam Rangka Pengembangan Wilayah Kab. Majalengka. Skripsi. Fakultas Teknologi. UNPAS. Bandung.

Badan Pusat Statistik Provinsi Jambi. 2016. Jambi dalam Angka 2006. BPS Provinsi Jambi. Jambi. . 2013. Produk Domestik Regional Bruto Provinsi Jambi Tahun 2010-2013. BPS Provinsi Jambi. Jambi. . 2015. Produk Domestik Regional Bruto Provinsi Jambi Tahun 2014-2015. BPS Provinsi Jambi. Jambi. . 2016. Produk Domestik Regional Bruto Provinsi Jambi Tahun 2015-2016. BPS Provinsi Jambi. Jambi.

Jhingan, ML. 2007. Ekonomi Pembangunan dan Perencanaan. Raja Grafindo Persada, Jakarta.

Gultom, elfrida. 2006. Ekonomi Makro. Raja Grafindo Persada, Jakarta.

Nindyantoro. 2004. Kebijakan Pembangunan Wilayah: Dari Penataan Ruang Sampai Otonomi Daerah. Jurusan Sosial Ekonomi Pertanian Fakultas Pertanian. IPB. Bogor.

Pranata, W, F. 2004. Analisis Sektor Basis Perekonomian dalam Pembangunnan Wilayah di Era Otonomi Daerah. Skripsi. Fakultas Pertanian. IPB. Bogor.

Purliana, Indah. 2003. Analisis Sektor Basis Perekonomian dan Peranan Fasilitas Pelayanan Terhadap Pembangunan Wilayah Kota Tegal. Skripsi. Fakultas Pertanian. IPB. Bogor.

Richardson, H. 2001. Dasar-Dasar Ilmu Ekonomi Regional. Fakultas Ekonomi Universitas Indonesia. Jakarta.

Sukirno, S. 2006. Ekonomi Pembangunan (Proses, Masalah, dan Dasar Kebijaksanaan). LPFE UI.Jakarta.

Sudirman, dkk (2017) Kajian Potensi Ekonomi Kota Jambi

Sudirman, Susilawati (2017) "Pengaruh Indeks Pembangunan Manusia dan Income perkapita terhadap konsumsi rumah tangga di Provinsi Jambi",

Tarigan, Robinson. 2005. Ekonomi Regional Teori dan Aplikasi. Bumi Aksara, Jakarta.

Usya, N. 2006. Analisis Struktur Ekonomi dan Identifikasi Sektor Unggulan di Kabupaten Subang. Fakultas Ekonomi dan Manajemen. IPB. Bogor. 
Widiaastuti, Nur. 2010. Analisis Sektor Unggulan Di Kabupaten Klaten Tahun 2004-2007.Fakultas Ekonomi. Muhamadiyah Surakarta. Surakarta.

Widodo, S.T. 2006. Indikator Ekonomi. Yogjakarta: Kanisius. 